\title{
Balancing Facial Muscle Forces in Surgical Procedures with Botulinum Toxin: A New Vision
}

\author{
Hermes Pretel ${ }^{1 *}$, Daniel Nastri de Luca², Déborah Laurindo Pereira Santos ${ }^{2}$, Luiz Henrique \\ Torres², Renato Torres Augusto Neto', Yuliana Del Pilar Vega Chacón ${ }^{2}$ and Raphael \\ Capelli Guerra ${ }^{2}$
}

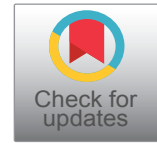

${ }^{1}$ Professor Collaborator Postgraduate Dental Sciences, Department of Restorative Dentistry, Araraquara School of Dentistry, UNESP-Univ Estadual Paulista, Araraquara, São Paulo, Brazil

${ }^{2}$ Postgraduate Dental Sciences, Araraquara School of Dentistry, UNESP-Univ Estadual Paulista, Araraquara, São Paulo, Brazil

*Corresponding author: Hermes Pretel, Department of Restorative Dentistry, Araraquara School of Dentistry, São Paulo State University-UNESP, Rua Humaitá, 1680-Centro-Araraquara/SP-14801-903, Brazil, Tel: +55-16-3301-6490

\begin{abstract}
Although the discovery of Botulinum Toxin is not recent, its application with functional and aesthetic purpose in the dental environment is considered new, and presents itself as an effective tool in treatments. One of the main highlights has been the assistance to pre-surgical preparations, as a way to improve the effectiveness of treatment, attenuating local muscle forces that may lead to a relapse or the failure of treatment. This topic is widely discussed, and suitable for all types of surgery: Periodontal, implant dentistry, temporomandibular joint, orthognathic and even fracture surgery of the stomatognathic complex. However, there is no well defined protocol about the muscles to be balanced, or the amount of drug to be applied. In view of this need, the purpose of this article is to propose some quantitative protocols for the application of Botulinum Toxin, and to describe the muscles that will have their biomodulated contractions according to their function in different surgical procedures.
\end{abstract}

\section{Keywords}

Botulinum toxin, Orofacial harmonization, Surgical procedures

\section{Introduction}

Botulinum toxin (BTX) has spread to the whole worId through the wide spectrum of use in various areas of medicine and dentistry. Since its introduction in clinical use more than 30 years ago, BTX has become a versatile medicine and is widely used in cosmetic and functional applications [1,2]. In view of the possible alternatives for its use it can be used in dentistry for the treatment of temporomandibular dysfunction, bruxism, tooth tightening, tension headaches, hypertrophy of the masseter, salorrhea, among other aesthetic functional treatments. The use of botulinum toxin type $A$ (BoNT/A) on cosmetic facial procedures is growing, and presents excellent results. However little has been described about its use in surgical planning of facial trauma, implants and orthognathic surgery [3]. This way, this article aims to describe about the important role of the toxin in these procedures.

\section{Botulinum Toxin}

Mechanisms of action: BTX is a protein produced by a gram-positive anaerobic bacterium called $C$. Botulinum [4], classified into seven types (A, B, C, D, E, F and $G)$ [5]. It acts through muscle relaxation by inhibiting the release of acetylcholine at the neuromuscular junction. This process involves three stages: Initially, I) The toxin binds to the cholinergic nervous terminal, then occurs the; II) Internalization/translocation of the membrane, and finally and III) Calcium-dependent inhibition of the neurotransmitter release.

The process involves three steps, and is well described in literature: I) Bonding: BoNT-A binds to a high

Citation: Pretel H, Luca DN, Santos DLP, Torres LH, Neto RTA, et al. (2020) Balancing Facial Muscle Forces in Surgical Procedures with Botulinum Toxin: A New Vision. Res Rep Oral Maxillofac Surg 4:046. doi.org/10.23937/2643-3907/1710046

Accepted: November 28, 2020; Published: November 30, 2020

Copyright: (c) 2020 Pretel H, et al. This is an open-access article distributed under the terms of the Creative Commons Attribution License, which permits unrestricted use, distribution, and reproduction in any medium, provided the original author and source are credited. 
Table 1: Description of the head and neck muscles, and strategies for application of botulinum toxin (Botulift - Medytox - South Korea) in pre and post-surgery.

\begin{tabular}{|c|c|c|c|c|c|c|}
\hline Muscle Name & ORIGIN & INSERTION & Action & Facial Expression & Quantity & Depth \\
\hline M. Nasal & $\begin{array}{l}\text { Jaw (canine } \\
\text { eminence) }\end{array}$ & $\begin{array}{l}\text { Wing of the nose } \\
\text { and lower portion } \\
\text { of the back }\end{array}$ & $\begin{array}{l}\text { Dilates and } \\
\text { compresses } \\
\text { the nose }\end{array}$ & Enoyed & $\begin{array}{l}2 U \text { Central } \\
1 U \text { Lateral }\end{array}$ & $\begin{array}{l}3 \text { A } 4 \mathrm{~mm} \\
\text { Perpendicular } \\
1 \text { A } 2 \mathrm{~mm} \\
\text { Parallel }\end{array}$ \\
\hline $\begin{array}{l}\text { M. Nasal } \\
\text { septum } \\
\text { depressor }\end{array}$ & $\begin{array}{l}\text { Alveolar } \\
\text { eminence of the } \\
\text { central incisor }\end{array}$ & Nasal septum & $\begin{array}{l}\text { Movement of } \\
\text { the nostrils }\end{array}$ & $\begin{array}{l}\text { Nose movement } \\
\text { when talking }\end{array}$ & 2 a $3 U$ & $\begin{array}{l}3 \text { A } 5 \mathrm{~mm} \text { (45 } \\
\text { degrees) }\end{array}$ \\
\hline $\begin{array}{l}\text { M. Orbicular of } \\
\text { the mouth }\end{array}$ & $\begin{array}{l}\text { "Bone: anterior } \\
\text { midline of } \\
\text { maxilla and } \\
\text { mandible } \\
\text { Muscle: angle of } \\
\text { the mouth where } \\
\text { fibers blend with } \\
\text { other muscles" }\end{array}$ & $\begin{array}{l}\text { Upper and lower } \\
\text { lip/Skin along the } \\
\text { mouth }\end{array}$ & $\begin{array}{l}\text { Brings lips } \\
\text { closer }\end{array}$ & Kiss & $\begin{array}{l}1 \mathrm{U} \text { per point } \\
\text { bilateral ( } 4 \text { a } 6 \\
\text { points) }\end{array}$ & $1 \mathrm{~mm}$ \\
\hline $\begin{array}{l}\text { M. Mouth angle } \\
\text { lifter }\end{array}$ & $\begin{array}{l}\text { Maxilla and } \\
\text { zygomatic } \\
\text { bone above the } \\
\text { foramen IO }\end{array}$ & Angle of mouth & $\begin{array}{l}\text { Elevate the } \\
\text { angle of the } \\
\text { mouth }\end{array}$ & $\begin{array}{l}\text { Strong smile- } \\
\text { mouth aisle } \\
\text { exposure }\end{array}$ & 2 a $5 U$ & 4 a $5 \mathrm{~mm}$ \\
\hline $\begin{array}{l}\text { M. Upper lip } \\
\text { lifter }\end{array}$ & $\begin{array}{l}\text { Maxilla and } \\
\text { zygomatic } \\
\text { bone above the } \\
\text { foramen IO }\end{array}$ & Upper lip & $\begin{array}{l}\text { Raiser and } \\
\text { everte the } \\
\text { upper lip }\end{array}$ & strong smile & 2 a $4 U$ & 3 a $4 \mathrm{~mm}$ \\
\hline $\begin{array}{l}\text { M. Upper lip and } \\
\text { nose wing lifter }\end{array}$ & $\begin{array}{l}\text { Maxilla (front } \\
\text { process) }\end{array}$ & $\begin{array}{l}\text { Nose wing and } \\
\text { upper lip }\end{array}$ & $\begin{array}{l}\text { Elevate and } \\
\text { everte the } \\
\text { upper lip and } \\
\text { dilate the } \\
\text { nostril }\end{array}$ & $\begin{array}{l}\text { Smile strong and } \\
\text { disgusted }\end{array}$ & 2 a $4 U$ & 3 a $4 \mathrm{~mm}$ \\
\hline M. Lower lip & Jaw base & Lower lip & $\begin{array}{l}\text { Traces lower } \\
\text { lip infero- } \\
\text { laterally }\end{array}$ & $\begin{array}{l}\text { When raising } \\
\text { the lower lip it } \\
\text { stretches the lower } \\
\text { lip }\end{array}$ & $2 U$ & $4 \mathrm{~mm}$ \\
\hline $\begin{array}{l}\text { M. Mouth angle } \\
\text { depressor }\end{array}$ & Mandible & Angle of mouth & $\begin{array}{l}\text { Depresses } \\
\text { the corner of } \\
\text { the mouth }\end{array}$ & $\begin{array}{l}\text { When raising } \\
\text { the lower lip-it } \\
\text { stretches the lower } \\
\text { lip loweing muscle }\end{array}$ & $2 \mathrm{U}$ & $4 \mathrm{~mm}$ \\
\hline M. Mentual & $\begin{array}{l}\text { Incisive jaw } \\
\text { bone }\end{array}$ & Mint skin & $\begin{array}{l}\text { Raises and } \\
\text { protracts the } \\
\text { lower lip }\end{array}$ & $\begin{array}{l}\text { Raise lower lip- } \\
\text { Duck beak }\end{array}$ & 2 a $3 U$ & 4 a $5 \mathrm{~mm}$ \\
\hline M. Platisma & $\begin{array}{l}\text { Sternum- } \\
\text { clavicular region }\end{array}$ & Jaw base & $\begin{array}{l}\text { Spread and } \\
\text { wrinkles the } \\
\text { skin of the } \\
\text { neck }\end{array}$ & $\begin{array}{l}\text { Lift and lower your } \\
\text { neck }\end{array}$ & $\begin{array}{l}1 \mathrm{U} \text { per point } \\
\text { bilateral }(20 \mathrm{a} \\
30 \text { points })\end{array}$ & $1 \mathrm{~mm}$ \\
\hline M. Masseter & Zygomatic arch & $\begin{array}{l}\text { Lateral side of the } \\
\text { branch and base of } \\
\text { the mandible }\end{array}$ & Jaw lift & $\begin{array}{l}\text { Occlusion and } \\
\text { contact of posterior } \\
\text { teeth }\end{array}$ & 9 a $25 \mathrm{U}$ & 10 a $13 \mathrm{~mm}$ \\
\hline M. Temporal & $\begin{array}{l}\text { Temporal pit/ } \\
\text { Sphenoid tube }\end{array}$ & $\begin{array}{l}\text { Coronoid process/ } \\
\text { Mandibular } \\
\text { temporal crest }\end{array}$ & $\begin{array}{l}\text { Jaw lifting } \\
\text { and retraction }\end{array}$ & $\begin{array}{l}\text { Occlusion and } \\
\text { contact of posterior } \\
\text { teeth }\end{array}$ & $\begin{array}{l}60 \% \text { (anterior } \\
0 \text { and } 40 \% \\
\text { (posterior) of } \\
\text { the masseter }\end{array}$ & 8 a $13 \mathrm{~mm}$ \\
\hline $\begin{array}{l}\text { M. Medial } \\
\text { pterygoid }\end{array}$ & $\begin{array}{l}\text { Pterygoid } \\
\text { process }\end{array}$ & $\begin{array}{l}\text { Medial side of } \\
\text { the branch and } \\
\text { mandibular } \\
\text { annulus }\end{array}$ & $\begin{array}{l}\text { Elevate, } \\
\text { protract and } \\
\text { lateral jaw } \\
\text { movement }\end{array}$ & $\begin{array}{l}\text { Opening, closing } \\
\text { and laterality }\end{array}$ & $5 U$ & 5 a $8 \mathrm{~mm}$ \\
\hline $\begin{array}{l}\text { M. Lateral } \\
\text { pterygoid }\end{array}$ & $\begin{array}{l}\text { Pterygoid } \\
\text { process }\end{array}$ & $\begin{array}{l}\text { Articular and } \\
\text { pterygoid disc }\end{array}$ & $\begin{array}{l}\text { Depress } \\
\text { and protract } \\
\text { the jaw/disc } \\
\text { and lateral } \\
\text { movement }\end{array}$ & $\begin{array}{l}\text { Opening, closing } \\
\text { and laterality }\end{array}$ & 2 a $3 U$ & $\begin{array}{l}\text { Direct muscular } \\
\text { or arthroscopic } \\
\text { route }\end{array}$ \\
\hline
\end{tabular}


affinity receptor (SNAP-25) predominantly found in the cholinergic neurons of the motor nerves through the binding domain of the heavy chain; II) Internalization/ translocation: Once the BoNT/A connects to the neuronal cell, the internalization process presumably intermediated by an endocytosis receptor begins; III) Neurotransmitter exocytosis: Inhibition of neurotransmitter exocytosis (acetylcholine) occurs through a light chaindependent zinc proteolytic activity, which selectively breaks the peptide bonds essential for neurotransmitter release. From this fomentation, it occurs the blockage of the acetylcholine vesicles with the cellular membrane of the nervous terminal [6].

In clinical terms, BTX induces prolonged blocking of nerve transmission by binding to pre-synaptic neurons in the first hour of action, specifically with subsequent muscle relaxation. Recovery occurs in two distinct phases, where initially the accessory terminals arise from the axon with the pre-synaptic terminal damaged and act to stimulate the muscles. After approximately 28 days, the main terminal slowly begins to recover its ability to release neurotransmitters, probably through the synthesis of new SNAP-25 receptors, with the disappearance of the accessory terminals. After just over 90 days, a period that correlates well with the duration of the clinically observed effect, recovery is essentially complete $[5,6]$.

\section{Diagnosis of Facial Muscle Pattern}

Patients can be classified into three groups, based on their facial muscle contractions and severity of expression mark prior to treatment.

\section{Kinetic}

Kinetic patients are those with regular muscle contraction and wrinkles during active expression, but not at rest. Generally these patients are not a concern in planning the balance of muscle forces.

\section{Hyperkinetics}

Hyperkinetic patients have too much muscle contraction, where repeated contractions are associated with the formation of horizontal wrinkles on the overlying skin, when they persist even at rest or when they occur markedly during facial expression generally interpreted as a sign of aging.

The evaluation of these patients must be careful, especially in case of Implantology and periodontics, thus avoiding risks of suture dehiscence and gingival retraction, especially in the mentual region.

\section{Hypertonic}

Hypertonic patients are those with inability to relax specific muscles related to muscle tension.

Such distinct anatomical characteristics and varied spectra determine contraction patterns of muscles peculiar to each person. This knowledge is essential for choosing the most appropriate application points, providing each patient with an individualized approach $[7,8]$.

In the preoperative patient evaluation, the definition of these profiles determines the type of injection, number of points and botulinum toxin units per point to be used (Table 1) [8]. Previous treatment with botulinum toxin provides the balance of hyperfunction mainly in patients with hypertonic pattern. Thus, when submitted to orthognathic surgery, fracture reduction surgery or atm surgery, among other reconstructive aesthetic surgical procedures, these patients may present minor problems such as: dehiscence of suture in the region of surgical accesses, loss of rigid internal fixation system, formation of pseudoarthrosis, minimizing gingival retraction in the region of the chin or areas of brake insertions mainly for implantology/periodontics [4].

Table 2: Guide for planning the muscles to be treated with botulinum toxin in surgical procedures.

\begin{tabular}{|l|l|l|l|l|}
\hline Muscle Name & ATM & Orthognatic & Implant & Reconstructive aesthetic \\
\hline M. Nasal & - & - & - & YES \\
\hline M. Nasal septum depressor & - & YES & - & YES \\
\hline M. Orbicular of the mouth & - & - & - & YES \\
\hline M. Mouth angle lifter & - & - & YES & YES \\
\hline M. Upper lip lifter & - & - & YES & YES \\
\hline M. Upper lip and nose wing lifter & - & - & YES & YES \\
\hline M. Lower lip & - & - & YES & YES \\
\hline M. Mouth angle depressor & - & - & YES & YES \\
\hline M. Mentual & - & YES & YES & YES \\
\hline M. Platisma & - & - & - & YES \\
\hline M. Masseter & YES & YES & YES & YES \\
\hline M. Temporal & YES & YES & YES & YES \\
\hline M. Medial pterygoid & YES & YES & YES & YES \\
\hline M. Lateral pterygoid & YES & YES & YES & YES \\
\hline
\end{tabular}


The Use of the Toxin in Various Surgical Procedures

As a way to simplify the protocols currently used for the use of botulinum toxin (Botulift - Medytox - South Korea) in facial muscles, we describe in tabular form surgical procedures, the muscles involved and the application of botulinum toxin in different treatments. However, it should be noted that the use of botulinum toxin in the muscles of facial mimicry is not recommendedor when to use cautious post-surgical analysis, because its use in conjunction with surgical procedures can hinder the evolution and evaluation of the postoperative period, and may mask possible lesions in different nerve branches (Table 2) [7,9].

\section{Discussion}

Much is known about the use of botulinum toxin in the field of orofacial harmonization for aesthetic purposes, but little is discussed about its use to achieve the balance of muscle forces that directly interfere in the treatment and prognosis of some facial procedures.

Orthognathic surgery is a procedure widely spread throughout the world, whose function is not only to improve facial aesthetics and functional occlusion, but also to achieve the recovery of the stomatognathic system by balancing the forces of the facial muscles [10]. Postoperative stability is an important point of discussion during surgical planning [11]. In 1982 Epker and Wessmberg reported the mechanisms of recurrence in orthognathic surgery as an interaction between surgical movement, condylar positioning and tension in paramandibular soft tissues $[12,13]$. Although myotomy has been described in the literature, it is presented with an invasive and uncomfortable technique, besides presenting risks to the patient [13]. The skeletal and neuromuscular changes that occur after the corrective procedure generate new incidences of forces, leading to interferences in the optimization, precision and predictability of treatment. In view of the fact that the performance of unbalanced muscular loads in the postoperative period may generate fractures of the synthesis material, propitiate deficiencies in the fixation and bone repair, as well as relapses and the need for new intervention. Among the clinical management options, botulinum toxin has proven effective in controlling post-surgical recurrence $[11,14]$.

The main muscles involved in mandibular mobility are: Masseter; temporal; medial and lateral pterygoid, which perform the movements of elevation, protrusion and lowering of the mandible [15]. In the literature several authors discuss that the force discrepancy of the neuromuscular system can generate and accentuate the intensity of malocclusions [16], as well as asymmetries can lead to imbalances in the masticatory forces. Altered oral rehabilitation causes neuromuscular discomfort, muscular hypertrophy and facial alteration; fur- thermore, it is estimated that this process takes around 90 days to rebalance the new oral condition. The same happens with surgical interventions for rehabilitation with multiple implants or implants of immediate load, as well as in cases of grafts. Studies suggest that the excess of muscle strength in the initial moments interfere with osseointegration and tissue repair. According to Branemark the load control conditions on the implants is one of the main factors for the success of osseointegration, being nowadays the most worrying, because it is directly related to major complications and loss of implants $[3,17]$.

In a similar way it happens in face traumas where several bone fixation points are necessary to prevent the mobility of the fractures by the intervention of muscular forces and thus prevent interference in bone repair. Thus, the use of botulinum toxin in facial traumatology can decrease the amount of bone synthesis material used. At the end of the treatment, it is essential that the muscles involved are relaxed and painless. If there is fatigue or muscle spasm in excess, the muscle fibers recruit more motor units to maintain the same tone of function, which generates overload, fatigue and local or referred pain $[16,17]$.

Thus, the infiltration of botulinum toxin two weeks before these interventions causes a homeostasis in which muscle forces are controlled pre-surgery and a more predictable postoperative with less muscle interference. It is of utmost importance to know the anatomy of the face and the muscles that interfere in each procedure, such as the correct administration of the toxin, its active principle and the safe dosage protocol recommended for each case, being this a strong ally in elective surgical planning [11].

Finally, there is great evidence of the benefits of botulinum toxin in hemifacial paralysis treatments. There are different surgical procedures that cause both transient and definitive paralysis as undesirable effects. The treatment with the botulinum toxin promotes a balance with the reduction of tonus on the normal side, and thus provides a balance with the paralyzed side. This treatment aims not only at aesthetic improvement, but also at functional improvement of the paralyzed side over time and of the treatments consecrated in the literature [18].

\section{Conclusion}

Botulinum toxin has been demonstrating beneficial effects in several areas of dentistry, where these professionals must demonstrate technical and scientific knowledge about head and neck structures. In view of the discussion proposed in this article, it is possible to consider botulinum toxin as an effective, safe and viable alternative for the prevention of some post-operative complications in surgically treated patients, in view of individual therapeutic planning for each case. Thus, it is 
possible to conclude that botulinum toxin contributes to the greater predictability of surgical planning, as well as adds values to the obited results, thus offering improvements in the quality of life of patients and greater ease for the surgeon.

\section{Conflict of Interest Statement}

The authors declare that they have no conflict of interest.

\section{References}

1. Eleopra R, Tugnoli V, Quatrale R, Rosetto O, Montecucco C (2004) Different types of botulinum toxin in humans. Mov Disord 8: S53-S59.

2. Jankovic J (2004) Botulinum toxin in clinical practice. Journal of Neurology, Neurosurgery and Psychiatry 75: 951957.

3. Pretel, Hermes, CaÇão (2018) Harmonização Orofacial. (1 ${ }^{\text {st }}$ edn) Curitiba: Editora Plena 2: 188.

4. Majid OW (2010) Clinical use of botulinum toxins in oral and maxillofacial surgery. International Journal of Oral and Maxillofacial Surgery 39: 197-207.

5. Mijiritsky E, Mortellaro C, Rudberg O, Fahn M, Basegmez C, et al. (2016) Botulinum toxin type a as preoperative treatment for immediately loaded dental implants placed in fresh extraction sockets for full-arch restoration of patients with bruxism. J Craniofac Surg 27: 668-670.

6. Wheeler A, Smith HS (2013) Botulinum toxins: Mechanisms of action, antinociception and clinical applications. Toxicology 306: 124-146.

7. Wang $S$ yi, Yue $J, X u Y$ xiang, $X u e ~ L$ fa, $X i a o ~ W$ lin, et al. (2014) Preliminary report of botulinum toxin type $A$ injection at trigger point for treatment of trigeminal neuralgia: Experiences of 16 cases. Shanghai Kou Qiang Yi Xue 23: 117-119.

8. De Maio M, Ofenböck Magri I, Narvaes Bello C (2008) Bot- ulinum toxin: Relation between patien type and duration of the effect. Cir Plast Ibero-Latinoamericana.

9. Docherty $N$ (2012) Netter's head and neck anatomy for dentistry. ( $2^{\text {nd }}$ edn), Br Dent J.

10. Kim MJ, Kim SG, Park YW (2002) Positional stability following intentional posterior ostectomy of the distal segment in bilateral sagittal split ramus osteotomy for correction of mandibular prognathism. J Cranio-Maxillofacial Surg 30: 35-40.

11. Seok H, Kim SG (2018) Correction of malocclusion by botulinum neurotoxin injection into masticatory muscles. Toxins 10: 27.

12. Epker BN, Wessberg GA (1982) Mechanisms of early skeletal relapse following surgical advancement of the mandible. Br J Oral Surg 20: 175-182.

13. Wessberg GA, Schendel SA, Epker BN (1982) The role of suprahyoid myotomy in surgical advancement of the mandible via sagittal split ramus osteotomies. J Oral Maxillofac Surg 40: 273-277.

14. Dickers C, Giannini L, Esposito L, Maspero C, Bellincioni F, et al. (2009) Neuromuscolar effects caused by orthopedic-functional therapy | Risposta neuromuscolare indotta da terapia ortopedico-funzionale. Mondo Ortod 34: 245-253.

15. Okeson JP (2008) The Classification of Orofacial Pains. Oral and Maxillofacial Surgery Clinics of North America 20: 133-144.

16. Farronato G, Giannini L, Galbiati G, Stabilini SA, Sarcina $M$, et al. (2015) Functional evaluation in orthodontic surgical treatment: Long-term stability and predictability. Prog Orthod 16: 30

17. Luvisetto S, Gazerani P, Cianchetti C, Pavone F (2015) Botulinum toxin type a as a therapeutic agent against headache and related disorders. Toxins 7: 3818-3844.

18. Cooper L, Lui M, Nduka C (2017) Botulinum toxin treatment for facial palsy: A systematic review. J Plast Reconstr Aesthet Surg 70: 833-841. 